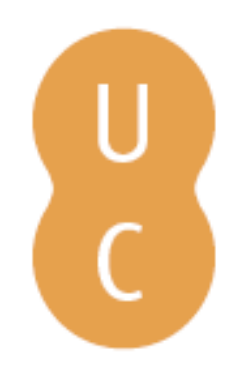

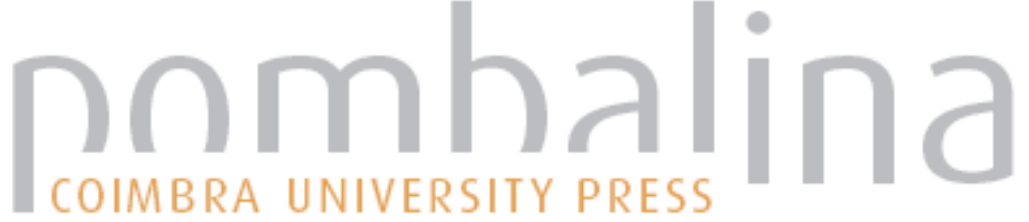

Determination of paraquat in blood and urine by liquid chromatography-electrospraymass spectrometry

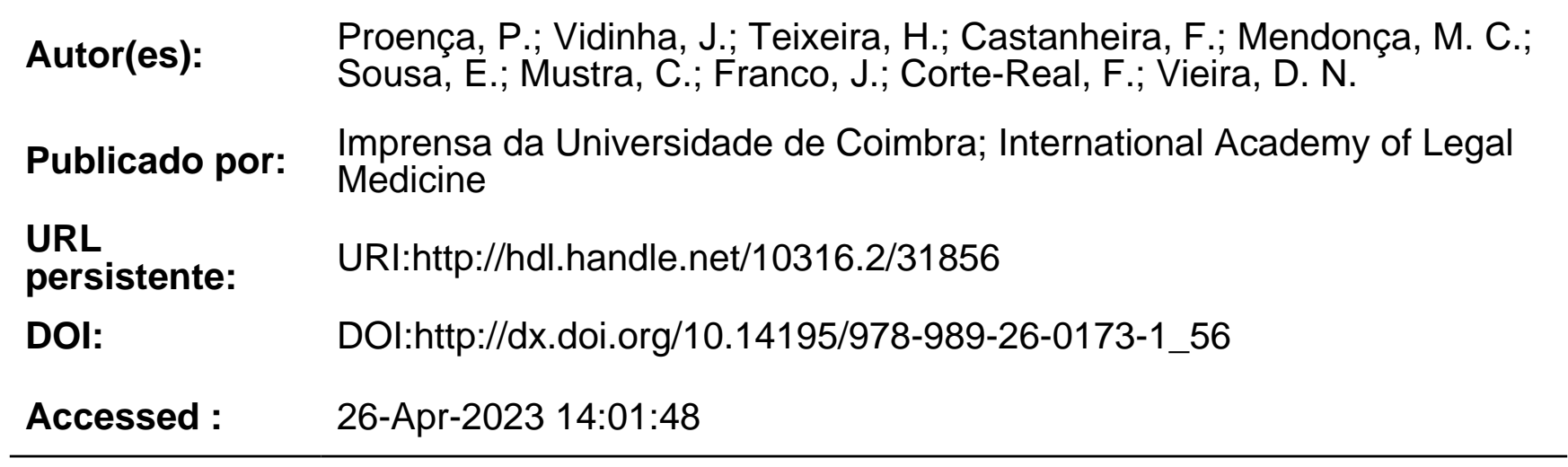

A navegação consulta e descarregamento dos títulos inseridos nas Bibliotecas Digitais UC Digitalis, UC Pombalina e UC Impactum, pressupõem a aceitação plena e sem reservas dos Termos e Condições de Uso destas Bibliotecas Digitais, disponíveis em https://digitalis.uc.pt/pt-pt/termos.

Conforme exposto nos referidos Termos e Condições de Uso, o descarregamento de títulos de acesso restrito requer uma licença válida de autorização devendo o utilizador aceder ao(s) documento(s) a partir de um endereço de IP da instituição detentora da supramencionada licença.

Ao utilizador é apenas permitido o descarregamento para uso pessoal, pelo que o emprego do(s) título(s) descarregado(s) para outro fim, designadamente comercial, carece de autorização do respetivo autor ou editor da obra.

Na medida em que todas as obras da UC Digitalis se encontram protegidas pelo Código do Direito de Autor e Direitos Conexos e demais legislação aplicável, toda a cópia, parcial ou total, deste documento, nos casos em que é legalmente admitida, deverá conter ou fazer-se acompanhar por este aviso.

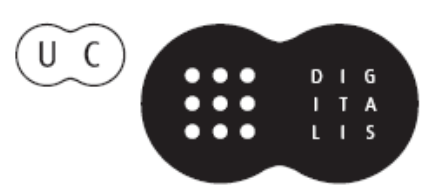




\section{Duarte Nuno Vieira Anthony Busuttil \\ Denis Cusack • Philip Beth}
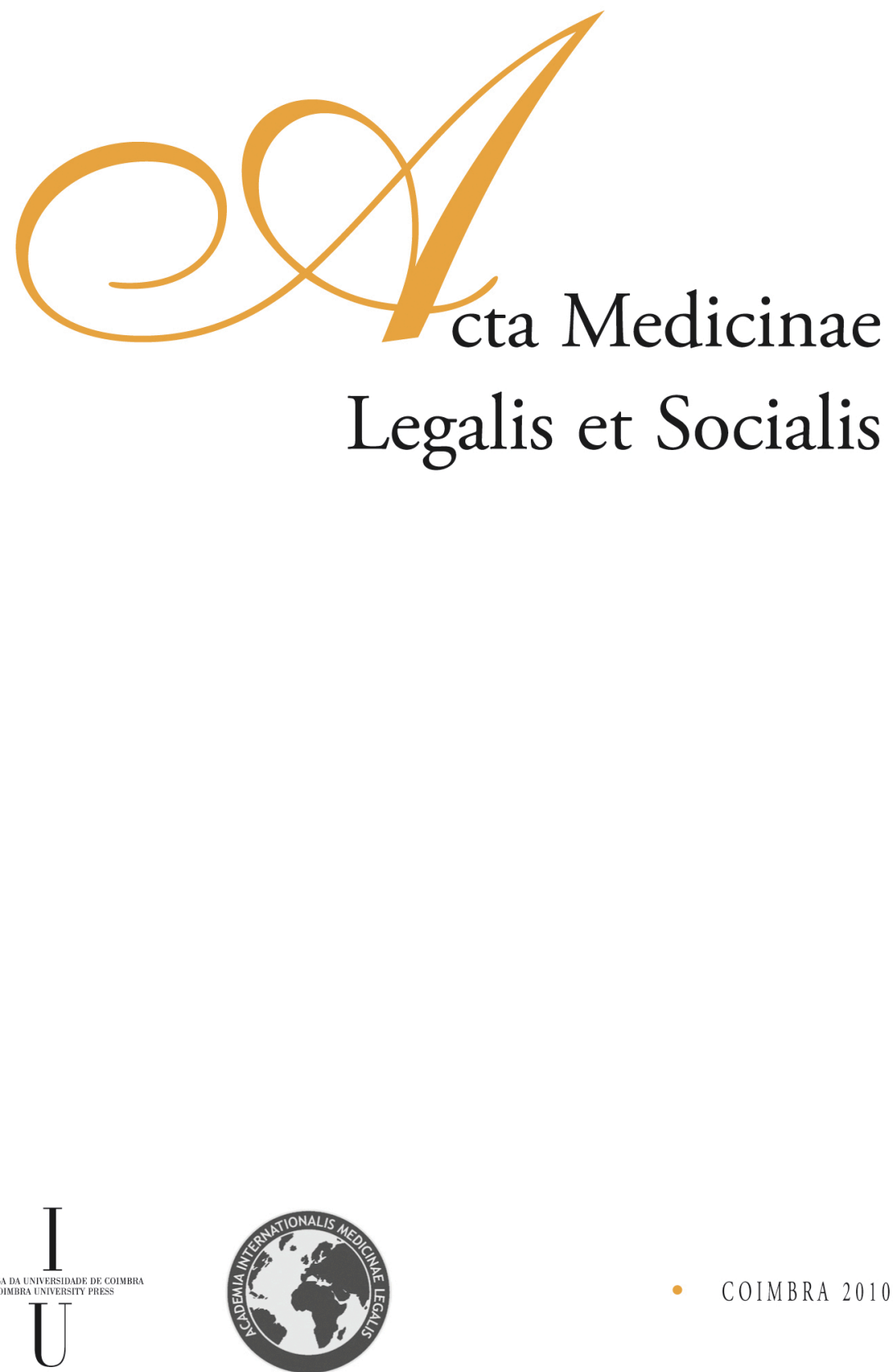
P. Proença ${ }^{1}$, J. Vidinha ${ }^{1}$, H. Teixeira ${ }^{1,2}$, F. Castanheira ${ }^{1}$, M. C. Mendonça ${ }^{1,2}$, E. Sousa $^{1}$, C. Mustra ${ }^{1}$, J. Franco ${ }^{1}$, F. Corte-Real ${ }^{1,2}$, D. N. Vieira ${ }^{1,2}$

${ }^{1}$ Centre Branch of the National Institute of Legal Medicine, Coimbra, Portugal

${ }^{2}$ Faculty of Medicine, University of Coimbra, Portugal

\title{
DETERMINATION OF PARAQUAT IN BLOOD AND URINE BY LIQUID CHROMATOGRAPHY-ELECTROSPRAY-MASS SPECTROMETRY.
}

\begin{abstract}
Paraquat (PQ) is a toxic quaternary ammonium compound widely used in agriculture. Numerous cases of paraquat intoxication have been reported either accidentally or intentionally as suicidal attempts.

A method for the determination of the herbicide PQ in blood and urine samples was developed using liquid chromatography-(electrospray ionization) mass spectrometry (LCESI-MS), following extraction with Oasis ${ }^{\circledR}$ WCX solid-phase cartridges. Chromatographic separation was achieved using an Atlantis ${ }^{\circledR}$ HILIC silica column, eluted isocratically with acetonitrile and ammonium formate $(200 \mathrm{mM})$ buffer, $\mathrm{pH} 3.8$, at a $300 \mu \mathrm{L} / \mathrm{min}$ flow rate. Quantitation was achieved by the addition of ethyl paraquat as internal standard (IS). The compounds were detected monitoring two ions for PQ $(\mathrm{m} / z 185$ and $m / z 171$ ) and $m / z 213$ for the IS. The method was applied to determine PQ in two cases: a non fatal case, a 42 -year-old female with $0.13 \mu \mathrm{g} / \mathrm{mL}$ PQ concentration in blood and $6.29 \mu \mathrm{g} / \mathrm{mL}$ in urine and a lethal case, a 51 -year-old male with $0.27 \mu \mathrm{g} /$ $\mathrm{mL}$ PQ concentration in blood.

The authors developed a specific, sensitive and rapid assay for the identification and quantification of $\mathrm{PQ}$, very important for monitoring suspected paraquat intoxications in hospitals and subsequently help in the treatment of these patients.
\end{abstract}

\section{Introduction}

The herbicide paraquat (1,1'-dimetyl-4,4'-dipyridyl cation, PQ), has been encountered in several cases of accidental and suicidal poisonings. The dichloride salt of paraquat or methyl viologen is well known under the trade name Gramoxone ${ }^{\circledR}$ (a 20\% aqueous solution). Concentrated liquid formulations have been responsible for most (and more severe) poisonings than granular forms, which contain less PQ. Although normal use of the herbicide does not present a serious health risk, many successful suicide attempts are often the result of the ingestion of concentrated forms of PQ [1-2].

Paraquat has low but rapid gastrointestinal absorption (5-10\%). Peak plasma concentrations appear in less than $2 \mathrm{~h}$. Following ingestion, PQ is actively transported to all major organs, especially to the lung, where it is reduced to form highly reactive free radicals. It is slowly excreted unchanged in urine and feces [3-4]. 
A wide variety of analytical techniques have been reported to determine PQ in biological samples, including gas chromatography (GC) [5-6], GC/mass spectrometry (MS) [7], high-performance liquid chromatography (LC) [8-13], LC/MS [14-15] and LC/MS/MS [16-19]. However, most of them require a complicated and a timeconsuming sample pretreatment.

Because this substance is ionic, solid-phase extraction (SPE) and HPLC usually have been accomplished with the aid of an ion-pairing reagent such as an alkyl sulphonic acid. LC-MS provides the analyst with a more sensitive and highly selective analytical method for paraquat. Strong cation exchange-based SPE methods that do not require ion-pairing reagents have been employed successfully, but the strong salts or strong acids used for elution are difficult to remove and are serious impediments to optimal LC-MS analysis. In order to overcome these problems, a new type of sorbents has been developed [20] for the retention of quaternary ammonium compounds and strongly basic organic compounds. The Oasis WCX sorbent incorporates a weak cation-exchanger bound to a polymeric reverse-phase particle. An Atlantis HILIC column was utilized for LC using no ion-pairing reagents.

This work presents two cases due to oral ingestion of Gramaxone ${ }^{\circledR}$, and describes a sensitive, specific, and rapid LC-ESI-MS method used to detect, confirm and quantify PQ in blood and urine samples.

\section{Case reports}

The first report describes a successful clinical case regarding the intoxication of a 42-year-old woman by a presumed lethal dose of paraquat. After hospital treatment this patient has shown a gradual return to normal spirometry values from the marked reduction that occurred at the time of paraquat intoxication. PQ was detected in blood and urine at levels of $0.13 \mu \mathrm{g} / \mathrm{mL}$ and $6.29 \mu \mathrm{g} / \mathrm{mL}$, respectively. Blood and urine samples were sent again to our laboratory 7 days after intoxication. PQ was not detected in blood and PQ urine concentration found was $0.18 \mu \mathrm{g} / \mathrm{mL}$. She survived.

The second case was a 51-year-old man admitted to the hospital with the information of a suicide attempt with intentional intake of Gramaxone ${ }^{\circledR}$. Treatment with repeated activated charcoal hemoperfusion was attempted (total time 14h). The patient developed acute renal and respiratory failure. He died from multiple organ failure 8 days after intoxication.

At autopsy, the internal examination revealed that both lungs were solid with acute hemorrhagic edema and both kidneys were deeply congested. Histological findings showed marked pulmonary congestion with numerous hemosiderin-laden macrophages.

The paraquat blood concentration found was $0.27 \mu \mathrm{g} / \mathrm{mL}$.

\section{Materials and methods}

\subsection{Chemicals and reagents}

Paraquat and ethyl paraquat (used as internal standard) were supplied by SigmaAldrich-Chemie GmbH (Steinheim, Germany). Each standard solution was prepared 
in methanol $(1 \mathrm{mg} / \mathrm{mL})$ and stored in plastic bottles at $+4^{\circ} \mathrm{C}$. Acetonitrile and methanol were HPLC-grade and were purchased from Merck (Darmstadt, Germany). Trifluoroacetic acid was from Riedel-de Haën (Seelze, Germany). Deionised and purified water was obtained using a Milli-Q system (Millipore, Molsheim, France). Solid-phase cartridges Oasis ${ }^{\circledR}$ WCX, $(60 \mathrm{mg}, 3 \mathrm{cc})$ were purchased from Waters (Milford, MA). The phosphate buffer ( $\mathrm{pH} 7.0$ ) was prepared by dissolving $0.12 \mathrm{~g}$ of $\mathrm{NaH} 2 \mathrm{PO} 4$ into a $100 \mathrm{~mL}$ volumetric flask and brought to volume with deionized water. Ammonium formate buffer $200 \mathrm{mM}(13.0 \mathrm{~g} / \mathrm{L})$ was prepared with deionized water, and the $\mathrm{pH}$ adjusted to 3.6 with formic acid. The mobile phase was filtered through a $0.20 \mu \mathrm{m}$ filter (Schleicher \& Schuell) and degassed in an ultrasonic bath for 15 min just before use.

\subsection{Instrumentation}

The chromatographic system (LC) used was a Waters 2695 Alliance System and Atlantis ${ }^{\circledR}$ HILIC silica column $(2.1 \times 150 \mathrm{~mm}, 5 \mu \mathrm{m})$. The mobile phase consisted of

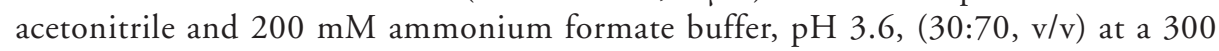
$\mu \mathrm{L} / \mathrm{min}$ flow rate. The column temperature was maintained at $35^{\circ} \mathrm{C}$. The injection volume was $10 \mu \mathrm{L}$.

A Waters 996 photodiode array detector operated on a 210-400 nm wavelength scan with a $1.2 \mathrm{~nm}$ resolution. The UV absorbance was measured at $258 \mathrm{~nm}$.

Mass spectrometry detection (MS) was carried out on a Waters ZQ 2000 single quadrupole mass spectrometer with an electrospray ionization (ESI) performed in positive mode. Full-scan spectra were recorded from $\mathrm{m} / \mathrm{z} 130-500$, at a scan time of $0.5 \mathrm{~s}$ and an interscan delay of $0.1 \mathrm{~s}$. The other main instrument settings were: capillary voltage $3.5 \mathrm{KV}$; cone voltage $40 \mathrm{~V}$; extractor $4 \mathrm{~V}$; ion energy 0.5 ; source temperature $120^{\circ} \mathrm{C}$; desolvation temperature $400^{\circ} \mathrm{C}$; cone gas $(\mathrm{N} 2)$ flow rate $0 \mathrm{~L} / \mathrm{h}$ and desolvation gas (N2) flow rate $600 \mathrm{~L} / \mathrm{h}$.

Instrument control, data acquisition and processing were achieved using Waters Empower software (Milford, MA).

\subsection{Sample preparation}

Controls and calibration samples were prepared by spiking drug-free whole blood and urine samples with standard solutions.

A $1 \mathrm{~mL}$ aliquot of whole blood or $1 \mathrm{~mL}$ of urine was spiked with $50 \mu \mathrm{L}$ of internal standard $(10 \mu \mathrm{g} / \mathrm{mL})$ and diluted with $2 \mathrm{~mL}$ of acetonitrile. Then the samples were vortex mixed and centrifuged for at $2500 \mathrm{rpm}$ for $10 \mathrm{~min}$. Extraction cartridges (Oasis ${ }^{\circledR}$ WCX, 3cc) were conditioned with $1 \mathrm{~mL}$ of methanol followed by $1 \mathrm{~mL}$ of deionized water. Each sample was loaded through a cartridge. It was then washed with $1 \mathrm{~mL}$ of phosphate buffer ( $\mathrm{pH}$ 7) followed by $1 \mathrm{~mL}$ of deionized water and $1 \mathrm{~mL}$ of methanol. After drying under vacuum for $10 \mathrm{~min}$, elution was carried out with 1.5 $\mathrm{mL}$ of acetonitrile/water/TFA (84:14:2, v/v). The eluate was evaporated to dryness under a nitrogen gas flow at $40^{\circ} \mathrm{C}$. The residue was dissolved in $100 \mu \mathrm{L}$ of methanol and an aliquot $(10 \mu \mathrm{L})$ was injected into the LC-ESI-MS system. 


\section{Results and discussion}

Calibration curves for paraquat in blood and urine samples were linear from 0.010 to $2.0 \mu \mathrm{g} / \mathrm{mL}$ in blood $\left(\mathrm{y}=0.0142 \mathrm{x}+0.1497\right.$ with $\left.\mathrm{r}^{2}=0.9994\right)$ and from 0.025 to 10.0 $\mu \mathrm{g} / \mathrm{mL}$ in urine $\left(\mathrm{y}=0.0141 \mathrm{x}+1.347\right.$ with $\left.\mathrm{r}^{2}=0.9994\right)$.

The detection limit of PQ in blood and urine samples was $0.004 \mu \mathrm{g} / \mathrm{mL}$ and 0.007 $\mu \mathrm{g} / \mathrm{mL}$ respectively $(L O D, \mathrm{~S} / \mathrm{N}=3)$ and the lower limit of quantification $(L O Q, \mathrm{~S} /$ $\mathrm{N}=10$ ) was $0.012 \mu \mathrm{g} / \mathrm{mL}$ in blood and $0.024 \mu \mathrm{g} / \mathrm{mL}$ in urine. For intra-day and interday precision determinations, five replicate analyses were performed at each of the three studied concentrations. Relevant validation data for recovery and precision are presented in Table I. The method proved to be precise for paraquat, both in terms of intra-day and inter-day analysis, with coefficients of variation (CV) less than $20 \%$. In selectivity study, an analysis of blank blood samples showed there were no interfering peaks at the elution time of paraquat or the internal standard (ethyl paraquat).

Quantitation employed the selected ion-recording mode (SIR) using the $\mathrm{m} / \mathrm{z}$ corresponding to the most abundant product ion $[\mathrm{M}+\mathrm{H}]^{+}$at $\mathrm{m} / \mathrm{z} 185$ for paraquat and $m / z 213$ for the internal standard. Paraquat fragment ions, $m / z 171$ and $\mathrm{m} / z 144$, were due to the loss of the methyl group corresponding to $[\mathrm{M}+\mathrm{H}-\mathrm{CH} 3]^{+}$and due to the loss an $\mathrm{HCN}$ molecule $[\mathrm{M}+\mathrm{H}-\mathrm{CH} 3-\mathrm{HCN}]^{+}$, respectively. Both SIR and Scan acquisitions were performed in centroide mode. SIR mass chromatograms and mass spectrum in SCAN mode $(\mathrm{m} / \mathrm{z} 185)$ of the paraquat detected in the blood sample (case 2) are shown in Fig. 1.

The proposed solid-phase extraction procedure and LC-ESI-MS method provided an accurate assay for the determination of paraquat in blood and urine.

The authors developed a specific, sensitive and a rapid assay for the identification and quantification of paraquat, very important for monitoring suspected paraquat intoxications in hospitals and consequently help in the treatment of these patients. The procedure has also been applied to a fatal death case involving paraquat poisoning.

\section{References}

[1] R.D. Fairshter, A.F. Wilson, Paraquat poisoning: manifestations and therapy, Am. J. Med., 59: 751- 753, 1975.

[2] T.J. Haley, Review of the toxicology of paraquat (1,1'-dimethyl-4,4'-bipyridinium chloride), Clin. Toxicol., 14: 1-46, 1979.

[3] R.C. Baselt. Disposition of toxic Drugs and Chemicals in Man, $7^{\text {th }}$ ed. Biomedical Publications, 844-846, 2004.

[4] A.C. Moffat, M.D. Osselton, B. Widdop, Clarke's Analysis of Drugs and Poisons in pharmaceuticals, body fluids, and postmortem materials. $3^{\text {th }}$ ed. The Pharmaceutical Press, 1395-1396, 2004.

[5] A. Van Dijk., R. Ebberink, G De Groot, R.A. Maes, A rapid and sensitive assay for the determination of paraquat in plasma by gas-liquid chromatography, J. Anal. Toxicol., 1: 151- 154, 1977.

[6] S. Kawase, S. Kanno, S. Ukai, Determination of the herbicide paraquat and diquat in blood and urine by gas chromatography, J. Chromatogr., 283: 231- 240, 1984. 
[7] G. H. Draffan, R.A. Clare, D.L. Davies, G. Hawksworth, S. Murray, D.S. Davies, Quantitative determination of the herbicide paraquat by gas-liquid chromatographic and spectrometric methods, J. Chromatogr., 139: 311- 320, 1977.

[8] R. Gil, S.C. Qua, A.C. Moffat, High-performance liquid chromatography of paraquat and diquat in urina with rapid sample preparation involving ion-pair extraction on disposable cartridges of octadecyl-silica, J. Chromatogr., 255: 483- 490, 1983.

[9] K. Croes, F. Martens, K. Desmet, Quantitation of paraquat in serum by HPLC-DAD, J. Anal. Toxicol., 17: 310- 312, 1993.

[10] S. Ito, T. Nagata, K.Kudo, K Kimura, T. Imamura, Simultaneous determination of paraquat and diquat in human tissues by high-performance liquid chromatography, J. Chromatogr., 617: 119-123, 1993.

[11] K. Arys, J. Van Bocxlaer, K. Clauwaert, W. Lambert, M. Piette, C. Van Peteghem, A. De Leenheer, Quantitative determination of paraquat in a fatal intoxication by HPLC-DAD following chemical reduction with sodium borohydride, J. Anal. Toxicol., 4: 116- 121, 2000.

[12] P. Paixão, P. Costa, T. Bugalho, C. Fidalgo, L.M. Pereira, Simple method for determination of paraquat in serum of human patients by high-performance liquid chromatography, J. Chromatogr. B, 775: 109- 113, 2002.

[13] S. Hara, N. Sasaki, D. Takase, S. Shiotsuka, K. Ogata, K. Futagami, K. Tamura, rapid and sensitive HPLC method for the simultaneous determination of paraquat and diquat in human serum, Analytical Sciences, 23: 523- 526, 2007.

[14] R. Castro, E. Moyano, M. T. Galceran, Ion-pair liquid chromatography-atmospheric pressure ionization mass spectrometry for the determination of quaternary ammonium herbicides, J. Chromatogr., 830: 145- 154, 1999.

[15] M. Yoshida, T. Watabiki, T. Tokiyasu, N. Ishida, Determination of paraquat and diquat by liquid chromatography-thermospray mass spectrometry, J. Chromatogr., 628: 235- 239, 1993.

[16] R. Castro, E. Moyano, M. T. Galceran, Determination of quaternary ammonium pesticides by liquid chromatography-electrospray tandem mass spectrometry, J. Chromatogr., 914: $111-121,2001$.

[17] Xiao-Pen Lee, T. Kumazawa, M. Fujishiro, C. Hasegawa, T. Arinobu, H. Seno, A. Ishii, K. Sato, Determination of paraquat and diquat in humam body fluids by liquid chromatographyelectrospray tandem mass spectrometry, J. Mass Spectrom., 39: 1147- 1152, 2004.

[18] O. Núñez, E. Moyano, M. T. Galceran, Time-of-flight high resolution versus triple quadrupole tandem mass spectrometry for the analysis of quaternary ammonium herbicides in drinking water, Analytica Chimica acta, 525: 183- 190, 2004.

[19] M. M. Ariffin, R.A. Anderson, LC/MS/MS analysis of quaternary ammonium drugs and herbicides in whole blood, J. Chromatogr. B, 842: 91- 97, 2006.

[20] M. S. Young, K. M. Jenkins, Oasis ${ }^{\circledR}$ WCX: a novel mixed-mode SPE sorbent for LC-MS determination of paraquat and other quaternary ammonium compounds, Recent Applications in LC-MS, in LC.GC Eur., 17: 51- 52, 2004. 

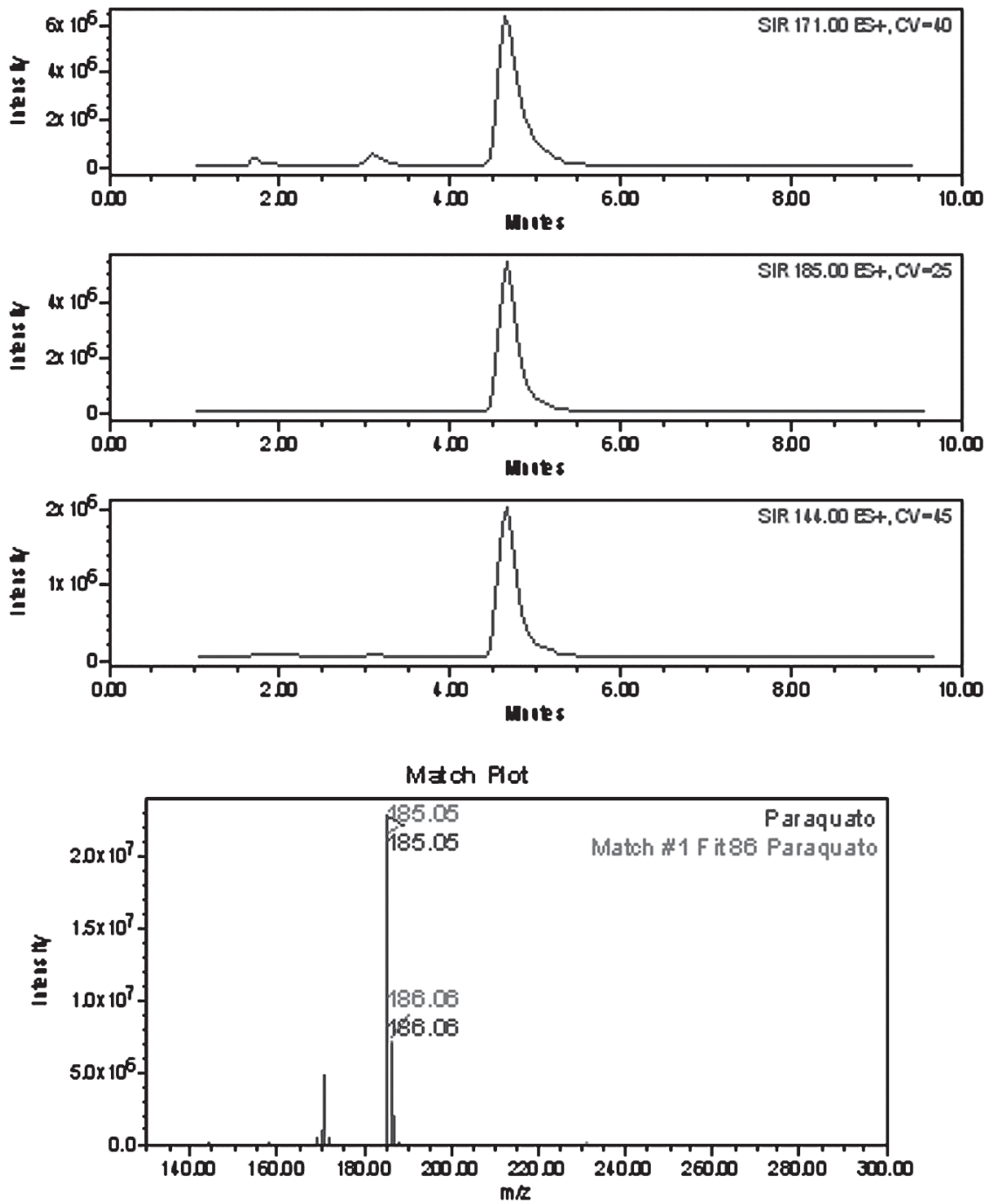

Figure 1 - SIR mass chromatograms and mass spectrum in SCAN mode (m/z 185), of paraquat in postmortem blood sample (case 2).

\begin{tabular}{|c|c|c|c|c|c|c|}
\hline & $\begin{array}{c}\text { Concentration level } \\
\text { (ug/taL) }\end{array}$ & $\begin{array}{c}\text { Recousey } \\
\text { (yo) }\end{array}$ & $\begin{array}{c}\text { Intra-dxy CV } \\
(P(0)\end{array}$ & $\underset{(y 0)}{\text { Intex-dxy CV }}$ & & n. \\
\hline & 0.025 & $60 \pm 8.7$ & 10.4 & 4.2 & $\cdot$ & 5 \\
\hline \multirow[t]{2}{*}{ BLOOD } & 0.25 & $58 \pm 7.7$ & 6.0 & 6.7 & & 5 \\
\hline & 1 & $: \quad 67 \pm 1.8$ & 10.2 & 13.3 & : & 5 \\
\hline
\end{tabular}

Table I - Validation data of recovery and precision for paraquat. 